Elvehjem, C. A., Hart, E. B. \& Sherman, W. C. (1933). F. biol. Chem. 1o3, 6r.

Friedemann, T. E. \& Frazier, E. I. (1950). Arch. Biochem. 26, 36r.

Gibbs, H. D. (1911). Philipp. F. Sci. 6, I47.

Hochberg, M., Melnick, D. \& Oser, B. L. (1945). F. Nutr. 30, 201.

Imperial Bureau of Animal Nutrition (1937). Tech. Commun. Bur. Anim. Nutr., Aberd., no. 9.

Kingsley, H. N. \& Parsons, H. T. (r947). F. Nutr. 34, 32 I.

Lane, J. H. \& Eynon, L. (1923). F. Soc. chem. Ind., Lond., 42, 32T.

National Research Council (1948). Repr. nat. Res. Coun., Wash., no. I29.

Parsons, H. T., Williamson, A. \& Johnson, M. L. (1945). F. Nutr. 29, 373.

Price, E. L., Marquette, M. M. \& Parsons, H. T. (1947). F. Nutr. 34, 31 I.

Pringle, W. J. S. (1946). Analyst, 71, 490 .

Shackleton, L. \& McCance, R. A. (1936). Biochem. F. 30, 582 .

\title{
Hexosamine in Human and Cow's Milk
}

\author{
By CONSTANCE A. C. ROSS \\ University Department of Infectious Diseases and Knightswood Hospital, Glasgow
}

(Received 27 November 1952)

It is generally recognized that the incidence of diarrhoea and vomiting in infancy is much higher in babies receiving cow's milk than in those who are breast fed, but the precise roles played by infection and nutrition in this disease syndrome are still uncertain. As a result of the examination of the amino-acids excreted in the faeces of infants receiving these two kinds of milk it has already been suggested that the type of diet may be closely related to the establishment of certain types of Bacterium coli (Ross, 1951). During an investigation of the amino-acid composition of the protein from human and cow milk by means of paper chromatography it was frequently noticed that a spot appeared on chromatograms of hydrolysed human milk protein that was absent on those from the hydrolysed protein from cow's milk. The identification of this spot as a hexosamine and the probable reason for its occurrence is the subject of the present communication.

\section{EXPERIMENTAL}

Milk samples used for chromatography. (a) Human milk. Milk was obtained from five mothers at varying stages of lactation. The milk was taken with a breast pump at the same time each day and at least $4 \mathrm{~h}$ after the previous feed. Three samples were taken at each withdrawal, sample $A$ before the infant was put to the breast, and samples $B$ and $C$ after the child had suckled for 5 and 10 min, respectively. A pooled sample, D, was obtained by mixing equal parts of A, B and C. (b) Cow's milk. A representative sample was taken from the whole milking of two Ayrshire cows in mid-lactation, another from the bulk milk of a herd of thirty-six cows and two samples from the commercial milk supplied to the hospital. In addition, two samples of National Dried Milk, one a full-cream and the other a half-cream powder, were reconstituted to give a protein content equal to that of cow's milk. 
Preparation of protein for chromatography. Protein was precipitated by the addition of I part of milk to 2 parts of a mixture of equal volumes of $0.67 \mathrm{~N}-\mathrm{H}_{2} \mathrm{SO}_{4}$ and $10 \%$ $(\mathrm{w} / \mathrm{v})$ sodium tungstate. The precipitate was filtered and dried in vacuo over calcium chloride. The protein was hydrolysed with $6 \mathrm{~N}-\mathrm{HCl}$ in a sealed tube for $24 \mathrm{~h}$ at $I 10^{\circ}$, and humin was removed by centrifuging. The hydrolysate was evaporated, twice taken up in water and re-evaporated. The residue was dissolved in a small volume of water to give about $17 \mathrm{mg} \mathrm{N} / \mathrm{ml}$., and ro $\mu$ l. were applied to the filter paper (Whatman no. 4). For the better detection of cystine and methionine the dried spot was oxidized with hydrogen peroxide (Dent, 1947). A spot of the non-hydrolysed protein was obtained by applying $20 \mu$ l. of the liquid milk to the filter paper. Hydrolysed and non-hydrolysed specimens were run simultaneously. Two-dimensional chromatography using butanol-acetic acid-phenol and phenol-collidine solvents was employed, with ninhydrin in $n$-butanol $(0.1 \% \mathrm{w} / \mathrm{v})$ as the detecting agent.

\section{RESULTS}

The amino-acid pattern in all the hydrolysed samples of both human and cow's milk was essentially the same except for one spot, of faint intensity, which appeared in many of the samples of mature human milk but was absent from all the samples of cow's milk. It was not present in any of the chromatograms from non-hydrolysed specimens. In both pairs of solvents, phenol-collidine and butanol-acetic acid-phenol, this spot had $R_{F}$ values and a position on the paper suggesting glucosamine (Aminoff, Morgan \& Watkins, 1950). When glucosamine was added to the hydrolysate the colour of the spot was considerably intensified. Spraying with ammoniacal silver nitrate (Partridge \& Westall, 1948) in place of ninhydrin solution produced a brown coloration in this area. Treatment of the area on a fresh chromatogram with alkaline acetylacetone followed by acid Ehrlich's reagent (Elson \& Morgan, 1933; Partridge \& Westall, 1948) produced a cherry-red spot. A definite colour with this reagent was only obtained when 20-30 $\mu$ l. hydrolysate was used. It appears likely therefore that the spot was a hexosamine, probably glucosamine, although in view of the difficulty of separation, chondrosamine may also have been present (Annison, James \& Morgan, 1951). By running various quantities of glucosamine and comparing the resulting spots with the spot on the chromatograms from human milk, a rough assessment of the amount of glucosamine present in human milk protein was obtained $(0.05-$ $0.1 \%$ ).

In Table I the occurrence of the hexosamine spot in the various samples of human milk protein is given. The spot was always present in the fore-milk A samples and usually in the others.

As the human milk samples had been obtained by use of the breast pump it seemed possible that some degree of tissue trauma, with liberation of mucin, might have occurred, so that on hydrolysis glucosamine would be formed. Hence a further series of nine A samples of milk was taken by manual expression from different women at stages of lactation varying from the $4^{\text {th }}$ to the roth week. The hexosamine spot was present in eight of these nine samples and did not appear to be correlated with the age of the mother, parity, the birth weight of the child or the stage of lactation. 
In order to determine whether the concentration of hexosamine would differ in the protein of colostral milk, samples of both human and cow colostrum were obtained. Of seven samples of human milk colostrum only two showed the normal hexosamine spot, and a further two showed a faint trace. The bovine colostrum was drawn from two cows $7-9 \mathrm{~h}$ after calving and thereafter at $24 \mathrm{~h}$ intervals for 4 days. Only a trace of hexosamine was present in the $7-9 \mathrm{~h}$ sample of each cow.

Table $\mathrm{r}$. The occurrence of hexosamine in samples of human milk. For description of samples A, B, C and D see text, $p .259$.

Patient
no.
I
2
3
4
5

$\begin{array}{cccc}\text { Sample } & \text { D } \\ \mathbf{A} & \mathbf{B} & \mathbf{C} & \mathbf{D} \\ + & + & + & + \\ + & + & + & + \\ + & + & + & + \\ + & - & + & \text { Not determined } \\ + & - & - & \text { Not determined }\end{array}$

\section{DISCUSSION}

The presence of free hexosamine in the hydrolysed samples of human milk protein and its absence in the unhydrolysed samples indicates that it was present in combined form. The source is by no means certain but several possibilities may be mentioned.

From the work of Reineke, Williamson \& Turner (I94r), it would appear that a considerable amount of milk protein is synthesized from one of the blood globulins, a glycoprotein, which contains about $9 \%$ of a carbohydrate complex of galactose, mannose and glucosamine. Again, it has been demonstrated by Hewitt (I934) that a polysaccharide is present in serum proteins, and that it forms an integral part of the protein molecule. He showed that this 'bound carbohydrate' could only be removed by prolonged chemical hydrolysis or digestion with proteolytic enzymes. Determination of hexosamine and acetyl radicles in this carbohydrate complex indicated that it contained galactose, mannose and acetylhexosamine. It therefore seems possible that the hexosamine found in hydrolysed human milk protein might be derived from a serum protein to which the milk secreting cells were permeable.

Glucosamine is present in human blood-group substances. These have been demonstrated in the saliva, blood, gastric juice and urine of some individuals (Putkonen, I930), but no reports can be found of their presence in human milk. Witebsky, Anderson \& Heide (r942) have shown that an $R h$ antibody was present in the milk and serum of a mother whose child had erythroblastosis. In a subsequent investigation it was demonstrated that the titre of $R h$ agglutinin in colostrum at $24 \mathrm{~h}$ was equal to that in the mother's serum (Witebsky \& Heide, I943). These findings suggest that blood-group protein characteristic of the mother may be present in her milk.

The failure to detect hexosamine in the chromatograms from cow's milk indicates its absence or its presence in insufficient amount to be detected by chromatography. This might be related to the higher protein and lower carbohydrate content of cow's milk compared with human milk. Moreover, the infrequent finding of hexosamine 
in human colostrum might also be associated with its higher ratio of protein to carbohydrate. As colostral protein has a greater globulin content and higher levels of antibodies than mature milk, it would appear that hexosamine is not associated with antibody protein. It seems therefore unlikely that resistance to diarrhoea and vomiting of infancy is connected with the presence of hexosamine in human milk.

\section{SUMMARY}

I. Amino-acid partition chromatography revealed the presence of a hexosamine spot, of faint intensity, probably due to glucosamine, in most samples of protein from mature human milk and its absence from samples of cow's milk protein.

2. The hexosamine was not always present in the chromatograms of human and bovine colostrum.

I wish to express my grateful thanks to Dr R. Waite of the Hannah Dairy Research Institute for his guidance in this work and for his help in preparing the paper. I am also indebted to Dr Margaret Brown, Biochemistry Department, University College, Dundee, for carrying out the modification of Elson \& Morgan's test and to Dr Thomas Anderson for his interest and advice.

This investigation was carried out under a grant from the Advisory Committee for Medical Research of the Department of Health for Scotland.

\section{REFERENCES}

Aminoff, D., Morgan, W. T. J. \& Watkins, W. M. (I950). Biochem. F. 46, 426. Annison, E. F., James, A. T. \& Morgan, W. T. J. (195I). Biochem. F. 48, 477.

Dent, C. E. (1947). Biochem. F. 4r, 240.

Elson, L. A. \& Morgan, W. T. J. (1933). Biochem. F. 27, 1824.

Hewitt, L. F. (1934). Biochem. F. 28, 2080.

Partridge, S. M. \& Westall, R. G. (I948). Biochem. F. 42, 238.

Putkonen, T. (1930). Acta Soc. Med. 'Duodecim', quoted by E. Witebsky \& N. C. Klendshaj (I 943), F. exp. Med. 73, 655 .

Reineke, E. P., Williamson, E. B. \& Turner, C. W. (1941). F. biol. Chem. 138, 83 .

Ross, C. A. C. (I95I). Lancet, 26r, I90.

Witebsky, E., Anderson, G. W. \& Heide, A. (1942). Proc. Soc. exp. Biol., N. Y., 49, 179.

Witebsky, E. \& Heide, A. (1943). Proc. Soc. exp. Biol., N.Y., 52, 280.

Note added in proof. Since this paper was submitted for publication, the isolation from human milk of a specific growth factor for Lactobacillus bifidus has been reported (György, P. (1953). Pediatrics, N.Y. II, 98), and it has been shown to contain $\mathrm{N}$-acetyl glucosamine, fucose and galactose. 